\title{
THE DEVELOPMENT OF 'SNAKE AND LADDER' LEARNING MEDIA TO ENRICH INDONESIAN VOCABULARY IN THEMATIC INSTRUCTIONFOR FOURTH GRADE STUDENTS
}

\author{
Yohana Intan Pratiwi ${ }^{1 *}$, Y. Haris Nusarastriya ${ }^{2}$ \\ 1 PGSD Departement. FKIP Universitas Kristen Satya Wacana, Indonesia \\ 2 PGSD Departement. FKIP Universitas Kristen Satya Wacana, Indonesia
}

\begin{abstract}
Abstrak
This research method used was Research and Development (RnD) by adapting the research and development steps by Borg and Gall. This research aims to help fourth grade students to enrich their Indonesian vocabulary, and also to know the validity, effectiveness, and practicality of the developed product. The developed product was 'snake and ladder' learning media with 31 grade four students of SD Negeri 02 Bringin as the subjects of this research. The data collection technique in this research used test (evaluation questions) and non-test (observation, questionnaire, and documentation). The validity of the product was analyzed from the calculation of media and material expert test, whereas the effectiveness was analyzed using PairedSample T Test with SPSS program. The practicality of the media was analyzed from the result of the observation and questionnaire from teachers and students. From this research, it can be concluded that 'snake and ladder' learning media to enrich the students' Indonesian vocabulary in thematic instruction was proven as valid, effective, and practical. The validity was proven with the average score 4,90 (very good) by the media expert and 4,00 (good) by the material expert. The effectiveness of the product was proven by significance score which showed that the result of two evaluation tests, which were $\mathrm{X}_{1}$ (implementation of snake and ladder which has not been developed) and $\mathrm{X}_{2}$ (implementation of developed product), was significant with the amount 0,000 , and also $61 \%$ students got above average grade which was 86,93 . The practicality proof came from the teacher observation with the average score 5,00 (very good) and the questionnaire of students and teacher toward the developed product with the average score 4,94 (very good) and 5,00 (very good)
\end{abstract}

Keywords:

Learning media, snake and ladder, Indonesian vocabulary, thematic instruction

\section{Introduction}

Learning is one of the aspects of human activities in complex which is actually a product from continual interaction between development and experience. Learning is an effort which is consciously done by educators to teach students bay giving advice which is appropriate with other learning references to reach the desired goal (Trianto, 2010:17). In the implementation of formal learning, there are varied learning approaches applied in education unit, one of them is integrated thematic instruction approach. Thematic learning comes from certain theme or topic which is then elaborated from various aspects or reviewed from various perspectives of subjects usually taught in school (Kadir, 2015). Certainly, in delivering various subjects which are summarized in certain theme or topic needs language component as a communication tool to facilitate the delivery of the material. According to Tarigan, the quality of someone's language skills depends on the quantity of their vocabulary (Dian Hikmayana, 2013). The amount of someone's vocabulary will influence the delivery of their quality ideas. It can also affect the skills to interpret every absorbed sentence. The lack of students' Indonesian vocabulary can create misconception in certain material. Based on the observation result in SD Laboratorium Kristen Satya Wacana Salatiga and SD Negeri 02 Bringin Kabupaten Semarang, it was found that most students had a difficulty in understanding the vocabulary taught, hence it has impact on the students' comprehension in the material and the student' skills in delivering ideas in a good and proper Indonesian sentences. It 
happens because of some reasons, such as the less concentration that the students have on the learning or reading process, the laziness to read, parents' roles in the development of their children's language skills, gadget influence which decrease the students' concentration, and also the inadequate facility. In the learning process, the educators tend to give treatment to the students by giving texts then emphasizing new vocabularies. In this case, various factors of the students' difficulty in understanding the vocabulary and the way the educators teach are the proofs that the acts done by the educators have not answered the students' needs to understand the vocabularies. The students need to be facilitated with new ways to enrich their Indonesian vocabulary in order to have high enthusiasm in the learning process, hence the material will be well received. Learning media can be one of efforts in the learning process to attract the students' interest and also to improve the quality of education with the achievement of learning objectives. Learning media is a tool that can help the teaching and learning process and it functions to clarify the meaning of the delivered message, therefore it can reach the learning objective better and more perfectly (Cecep Kustandi and Bambang Sutjipto, 2013:8). Based on the observation result of two elementary schools, a research which aims to help the students comprehend the Indonesian vocabulary easier is conducted. This research develops learning media which is snake and ladder and it is implemented in thematic instruction for fourth grade students. This research is also aimed to investigate the validity, effectiveness, and practicality of the developed learning media which is snake and ladder.

\section{Method}

This study is a Research and Development (R\&D). Development research is a research method which is used to produce certain product and test the effectiveness of that product (Sugiyono, 2012). The research steps are done by adapting the research design by Borg and Gall. The research steps using Borg and Gall design might be limited for small-scale research (Emzir, 2013). The step done in this research used Borg and Gall up to stage 7 (out of 10 stages), which are : (1) Research and information collecting, (2) Planning, (3) Develop preliminary form of product, (4) Preliminary field testing, (5) Main product revision, (6) Main field testing, (7) Operational product revision. Those seven stages will be described as the research procedures as follow:

1. Research and Information Collection

The research and information collection stage was done to know the learning needs in the field. In this stage, field study and literature review was done. This is the first stage of Borg and Gall research design.

2. Planning

This stage began by planning the design of snake and ladder to enrich Indonesian vocabulary for fourth grade students. After the design has been set, material mapping was delivered for strengthening. Material mapping was started with the analysis of Core Competence and Basic Competence, and also set the objective and indicator in delivering the material. In this stage, entering the second stage by Borg and Gall.

3. Develop Preliminary form of Product

The third stage by Borg and Gall is described truly in this stage. This stage was started by designing product, collecting the materials, then managing the materials, and the last was the production.

4. Preliminary Field Testing

This stage is a summary of stage 4 to 7 by Borg and Gall. Learning media which has been developed will then be validated. Validation was done in two stages. The first stage was validation by the material expert, where the material and advice compatibility data obtained in this stage. Then, if needed, the advice could be used for the material revision. The second stage of the validation was done by the media expert. It was used to know the appropriateness of the media to be implemented. If needed, the advice in this stage could be used to revise the product.

The results of the material and product revision were used for a limited test for 10 students as the research subjects. From the evaluation result, then the product was revised. After that, a broad test was conducted for all students in the class which were 31 students, hence the result of this evaluation was used for product revision. The implementation of before and after the product was developed was done in limited and broad testing stage. The product which has not been developed yet (the original snake and ladder) was called $\mathrm{X}_{1}$, while the product which has been developed was called $\mathrm{X}_{2}$. This was done to get the data of effectiveness and practicality of the developed snake and ladder learning media. 
The above research procedures are then described in the following figure:

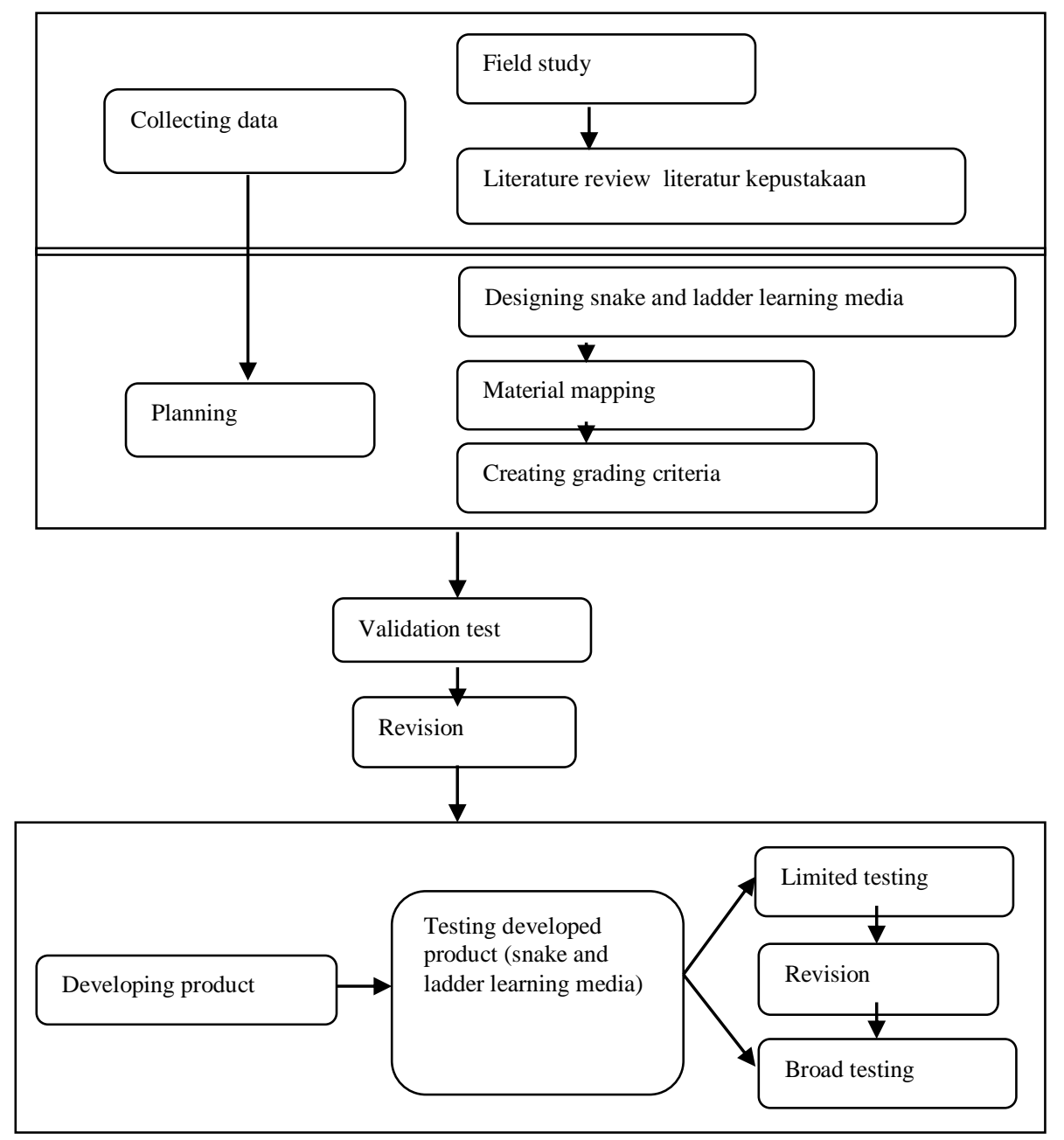

Figure 1. Research Procedure

Data collection technique used in this research is a test and non-test technique. Test technique in this research was when the students answered the evaluation questions after the implementation of $X_{1}$ and $\mathrm{X}_{2}$. The non-test technique was done using observation, questionnaire, and documentation. Observation was done by the researcher to get the data in formulating problem. The observation was also done by the teacher when the research was ongoing to observe the achievement of the learning process. The questionnaires were distributed to know the students' and teachers' responses toward the implementation of $X_{1}$ and $X_{2}$. The questionnaires were also distributed for the experts when they did validation tests toward the materials, learning media, and questions. The distributed questionnaires used 1-5 likert scale as a means to answer. Documentation in this study was in the form of pictures of learning media and its implementation process.

\section{Results And Discussion}

\section{Results}

1. Research and Information Collection Result

Research and information collection was done by doing field study and literature review. The field study was done by observing fourth grade students and interviewing teachers of grade 4 at SD Laboratorium Kristen Satya Wacana and SD Negeri 02 Bringin. Based on the observation and interview result, it was found that the lack of vocabulary for $4^{\text {th }}$ grade students was caused by several factors, such as the laziness to read, frequency of gadget usage which caused to their communication with the environment, and the method that the educators used to teach vocabulary which seemed to be less 
interesting. The educators tend to give reading texts, then they just emphasize on the vocabulary. On the other hand, based on the literature review, it was found that vocabulary is the main component of communication. In fact, the communication in the learning process is mainly done when the teachers deliver the material in written or spoken. Besides, several researchers and research subjects claimed that snake and ladder learning media is feasible. Snake and ladder can be one of alternatives to improve the students' vocabulary usage since this game allows them to actively interact with others.

2. Planning Result

In the planning stage, the objectives of the use of developed product has been set, which is to facilitate $4^{\text {th }}$ grade students in enriching their Indonesian vocabulary. It has been determined that the user of the developed product is $4^{\text {th }}$ grade students. Additionally, the material scope has been arranged by analyzing 2013 Curriculum with the Core Competence (KI) and Basic Competence (KD) which is adjusted with the objectives of the product usage.

3. Preliminary form of Product Development

This stage started by creating the picture frame of snake and ladder product before printing process. Adobe Photoshop Creative Suite 6 and Corel Draw X5 were used in the process of planning snake and ladder picture. After the picture was ready, it was printed using Metromedia Technologies (MMT) 3x x meters in size. The other devices in this learning media are: dice, education card, rules, and student worksheet (LKS). The dice $25 \times 25 \times 25$ centimeters in size was made of black plywood which was glued together with a glue and a duct tape. The numbers in the dice were made of paperboard which was stuck using a double-tape. The education card was a companion card in utilizing this snake and ladder learning media. This card was made using Corel Draw X5 in order to make it more interesting with the color and pictures in it. Then it was printed in a thick paper $7 \times 10$ centimeters in size, then it was laminated in order to be more durable and water resistant. The rule was a guidance in using this snake and ladder and it was made using Corel Draw X5. It was printed in a paper 17x20 centimeters in size, then it was laminated. The LKS was made using Microsoft Word 2010 and Corel Draw X5, and the cover was printed in a thick paper. It contained the materials that have been prepared from reviewing $\mathrm{KI}, \mathrm{KD}$, and formulating the indicators. The stories in the LKS were the researcher's own stories which still adjusted the main materials.

4. Experts Validation

There were 2 validations which come from material expert and media expert. The result from material expert toward the materials in the LKS and education card got 4,00 in average score with good category by using a questionnaire. In the instrument, there were several graded aspects, such as material, language, and originality aspect with 12 indicators in total. Then, the score from media expert was 4,90 in average with very good category. There were 20 indicators which were used to assess the developed learning media. The validated aspects by the media experts were design, language, typography, and completeness of the learning media, practicality, and originality aspect. After the validation test, revision was done based on the advice given by the experts. Therefore the product was said to be feasible to be implemented in the learning process.

5. Field Testing

1. Limited Testing

Limited Testing was conducted for $104^{\text {th }}$ grade students of SD Negeri 02 Bringin. In this test, an implementation was done toward $\mathrm{X}_{1}$ and $\mathrm{X}_{2}$ by referring to the Lesson Plan (RPP) that has previously passed. Teachers' response to this implementation was 2,70 AND 5,00 from each instrument with 10 indicators. Whereas the students' responses to $\mathrm{X}_{1}$ and $\mathrm{X}_{2}$ were reviewed from display, material content, and benefit aspect. Students' responses toward $X_{1}$ were 2,83 and 4,77 toward $X_{2}$. The students' responses toward $\mathrm{X}_{1}$ and $\mathrm{X}_{2}$ can be shown in Table 1.

Table 1. The Comparison of Students' Responses toward $\mathrm{X}_{1}$ and $\mathrm{X} 2$

\begin{tabular}{clcc}
\hline No & \multicolumn{1}{c}{ Aspect } & Result of X1 & Result of X2 \\
\hline 1 & Display & 2,70 & 4,60 \\
2 & Material content & 2,54 & 4,71 \\
3 & Benefit & 3,24 & 5,00 \\
\hline \multicolumn{2}{r}{ Average } & 2,83 & 4,77 \\
\hline
\end{tabular}

The teachers' observation to observe the achievement of the learning process which was suitable with the RPP got 3,86 for $\mathrm{X}_{1}$ implementation and 5,00 for X2 implementation. From the data, it is proven that snake and ladder media learning that has been developed is better to be implemented in learning process than the one that has not been developed yet.

After the end of the product implementation, the students answered the evaluation questions which have been previously validated by the material experts. The evaluation sheet consisted of 10 
multiple choices, and 10 matching questions, so there were 20 questions in total. The result shows that there are more students who could finish doing evaluation questions after the implementation of developed product than the implementation of the product that has not been developed yet. The interval class from $\mathrm{X}_{1}$ evaluation questions started from 55 as the lowest grade and 86 as the highest. Next, the result of X2 evaluation questions started from 70 as the lowest grade and 100 as the highest. The following tables show the frequency distribution of the students' grade in answering evaluation questions in limited test:

Table 2. Frequency Distribution of the Result of Evaluation Questions of $\mathrm{X}_{1}$

\begin{tabular}{ccc}
\hline Interval Class & Frequency (f) & Percentage \\
\hline $55-62$ & 2 & $2 \%$ \\
$63-70$ & 4 & $40 \%$ \\
$71-78$ & 3 & $30 \%$ \\
$79-86$ & 1 & $10 \%$ \\
\hline
\end{tabular}

Table 3. Frequency Distribution of the Result of Evaluation Questions of $\mathrm{X}_{2}$

\begin{tabular}{ccc}
\hline Interval Class & Frequency (f) & Percentage \\
\hline $70-77$ & 1 & $10 \%$ \\
$78-85$ & 0 & $0 \%$ \\
$86-93$ & 3 & $30 \%$ \\
$94-100$ & 6 & $60 \%$ \\
\hline
\end{tabular}

Based on the data from the implementation of the limited test, the improvement of the developed product was not conducted since the data of $\mathrm{X}_{2}$ (snake and ladder learning media that has been developed) implementation was in a very good category out of all information collection techniques used. In the next testing (broad testing), the researcher has to pay more attention on the technical matters of the learning process.

2. Broad Testing

The broad testing was conducted for all $314^{\text {th }}$ grade students of SD Negeri 02 Bringin. The research technique between limited and broad testing were the same, the different was on the amount of the research subject. Implementation of $\mathrm{X}_{1}$ and $\mathrm{X}_{2}$ was still conducted in limited testing. In this broad testing, the Lesson Plan (RPP) used was similar to the previous testing. The score of teachers' responses to the implementation of $\mathrm{X} 1$ was 2,50 and 5,00 for the implementation of $\mathrm{X}_{2} .31$ students also gave their responses to the implementation of $X_{1}$ and $X_{2}$. The average score of their responses were 3,28 for $X_{1}$ implementation and 4,94 for $\mathrm{X}_{2}$ implementation. The students' responses toward $\mathrm{X}_{1}$ and $\mathrm{X}_{2}$ can be shown in Table 4.

Table 4. The Comparison of Students' Responses toward $\mathrm{X}_{1}$ and $\mathrm{X}_{2}$

\begin{tabular}{cccc}
\hline No & Aspect & Result of X1 & Result of X2 \\
\hline 1 & Display & 3,52 & 4,97 \\
2 & Material content & 2,82 & 4,91 \\
3 & Benefit & 3,50 & 4,95 \\
\hline & Average & 3,28 & 4,94 \\
\hline
\end{tabular}

In the broad testing, teachers also observed the process of the research. From the observation, the average score of implementing $X_{1}$ in the learning process was 3,93 and 5,00 for implementing $X_{2}$ in the learning process. Based on the data, it is proven that the developed snake and ladder learning media is in a very good category to be implemented in the learning activities.

The following tables show the result of the evaluation questions that have been distributed after the implementation of $\mathrm{X}_{1}$ and $\mathrm{X}_{2}$ based on the students' grade.

Table 5. Frequency Distribution of the Result of Evaluation of $\mathrm{X}_{1}$ in Broad Testing

\begin{tabular}{ccc}
\hline Interval Class & Frequency (f) & Percentage \\
\hline $45-53$ & 4 & $13 \%$ \\
$54-62$ & 5 & $16 \%$ \\
$63-71$ & 4 & $13 \%$ \\
$72-80$ & 7 & $23 \%$ \\
$81-89$ & 3 & $10 \%$ \\
$90-100$ & 8 & $26 \%$ \\
\hline
\end{tabular}


Table 6. Frequency Distribution of the Result of Evaluation of $\mathrm{X}_{2}$ in Broad Testing

\begin{tabular}{ccc}
\hline Interval Class & Frequency (f) & Percentage \\
\hline $55-62$ & 3 & $10 \%$ \\
$63-70$ & 2 & $6 \%$ \\
$71-78$ & 2 & $6 \%$ \\
$79-86$ & 5 & $16 \%$ \\
$87-94$ & 8 & $26 \%$ \\
$95-100$ & 11 & $35 \%$ \\
\hline
\end{tabular}

The lowest grade of $\mathrm{X}_{1}$ evaluation is 45 and 100 as the highest grade with 74,52 as the average grade. Whereas the lowest grade of $\mathrm{X}_{2}$ evaluation is 55 and 100 as the highest with 86,93 as the average grade.

Table 7. Statistic Descriptive of the Evaluation Result of $\mathrm{X}_{1}$ and $\mathrm{X}_{2}$

\begin{tabular}{ccccccc}
\hline & $\mathrm{N}$ & Minimum & Maximum & Sum & Mean & Std. Deviation \\
\hline X1 & 31 & 45 & 100 & 2310 & 74.52 & 16.246 \\
X2 & 31 & 55 & 100 & 2695 & 86.93 & 13.458 \\
$\begin{array}{c}\text { Valid N } \\
\text { (listwise) }\end{array}$ & 31 & & & & & \\
\hline
\end{tabular}

In this research, the average grade in the class (mean) becomes the minimum criteria grade. In $\mathrm{X}_{1}$ evaluation, there were 18 students or $18 \%$ out of all students who have passed the minimum criteria grade. Whereas in $\mathrm{X}_{2}$ evaluation, there were 19 students or $61 \%$ out of all students who have passed the minimum criteria grade.

Table 8. The Minimum Criteria Grade of the Result of $\mathrm{X}_{1}$ and $\mathrm{X}_{2}$ Evaluations

\begin{tabular}{ccccc}
\hline Minimum & \multicolumn{2}{c}{ X1 Evaluation } & \multicolumn{2}{c}{ X2 Evaluation } \\
\cline { 2 - 5 } Criteria Grade & Amount & Percentage & Amount & Percentage \\
\hline Passed & 18 & $58 \%$ & 19 & $61 \%$ \\
Not passed & 13 & $42 \%$ & 12 & $39 \%$ \\
\hline
\end{tabular}

In order to know the effectiveness of the developed product, Paired Samples T Test was conducted. As the requirement, normality test was previously conducted with the following result:

Table 9. Normality Test of the Result of $\mathrm{X}_{1}$ and $\mathrm{X}_{2}$ Evaluations

\begin{tabular}{ccccccc}
\hline \multicolumn{4}{c}{ Kolmogorov-Smirnova } & \multicolumn{3}{c}{ Shapiro-Wilk } \\
\hline & Statistic & $\mathrm{df}$ & Sig. & Statistic & $\mathrm{df}$ & Sig. \\
$\mathrm{X} 1$ & .148 & 31 & .081 & .944 & 31 & .108 \\
$\mathrm{X} 2$ & .203 & 31 & .002 & .858 & 31 & .001 \\
\hline
\end{tabular}

The data of normality test of the result of $\mathrm{X}_{1}$ evaluation, the Kolmogorov-Smirnov ${ }^{\mathrm{a}}$ significance showed 0,081 . It means that the distribution of the data was normal since the significance score was more than 0,05 . While in the normality test of the result of $\mathrm{X}_{2}$ evaluation, the Kolmogorov-Smirnov ${ }^{\text {a }}$ significance showed 0,002 . It means that the distribution of the data was not normal since the significance score was lower than 0,05 .

After knowing the normality data of $\mathrm{X}_{1}$ and $\mathrm{X}_{2}$ evaluation, the next step was analyzing the statistic in parametric model. The parametric analysis that was used in IBM SPSS Statistics 16 program was by using Paired Sample T test. The following table shows the result of Paired Sample T test:

Table 10. The Result of Paired Sample T test

\begin{tabular}{|c|c|c|c|c|c|c|c|c|}
\hline & \multicolumn{5}{|c|}{ Paired Differences } & \multirow{3}{*}{$\mathrm{T}$} & \multirow{3}{*}{$\mathrm{df}$} & \multirow{3}{*}{$\begin{array}{l}\text { Sig. (2- } \\
\text { tailed) }\end{array}$} \\
\hline & \multirow[t]{2}{*}{ Mean } & \multirow{2}{*}{$\begin{array}{c}\text { Std. } \\
\text { Deviation }\end{array}$} & \multirow{2}{*}{$\begin{array}{l}\text { Std. Error } \\
\text { Mean }\end{array}$} & \multicolumn{2}{|c|}{$\begin{array}{c}95 \% \text { Confidence Interval } \\
\text { of the Difference }\end{array}$} & & & \\
\hline & & & & Lower & Upper & & & \\
\hline Pair 1 X1 - X2 & -12.419 & 5.143 & .924 & -14.306 & -10.533 & -13.445 & 30 & .000 \\
\hline
\end{tabular}


Based on the result, it was shown that the grade in column Sig. (2-tailed) was 0,000, which lower than 0,05 . Therefore, it can be concluded that there was a significant differences between the result of $\mathrm{X}_{1}$ and $\mathrm{X}_{2}$ evaluation, where the developed product was more effective.

According to the result of broad testing, the teaching and learning process was conducive and ran smoothly. The developed snake and ladder learning media has been categorized as a very good one and it did not need any revision.

\section{Discussion}

1. The validity of the developed snake and ladder learning media

The snake and ladder learning media has been proven as valid by material and media experts. The average score from the media experts validation was 4,90 with a very good category. While the material experts gave 4,00 as the average score with a good category.

2. The effectiveness of the developed snake and ladder learning media

The effectiveness of the developed snake and ladder learning media could be seen from the achievement of the learning objectives. It could be measured using an instrument in a form of evaluation test. Based on the data analysis of $X_{1}$ and $X_{2}$ evaluation test, the significance score was $0,000<0,005$. It means that $\mathrm{H}_{\mathrm{a}}$ was accepted and $\mathrm{H}_{0}$ was rejected. Since $\mathrm{H}_{\mathrm{a}}$ was accepted, then the developed snake and ladder learning media was effective to be implemented in a thematic instruction.

The effectiveness was also seen from the average score of the result of $\mathrm{X}_{2}$ evaluation which was higher than the $\mathrm{X}_{1}$. The average score of the result of $\mathrm{X}_{1}$ was 74,52 , while the $\mathrm{X}_{2}$ average score was 86,93 .

Based on the analysis result of teachers' questionnaire, the average score of $X_{1}$ was 2,50 with a not too good category, the $\mathrm{X}_{2}$ average was 5,00 with a very good category. The analysis result of students responses, the average score of $\mathrm{X}_{1}$ was 3,28 with a good category, while $\mathrm{X}_{2}$ average was 4,94 with a very good category. Therefore, it can be concluded that snake and ladder learning media was effective from the students' and teachers' objective opinions.

3. The practicality of developed snake and ladder learning media

The practicality was seen from the appropriateness of the implementation with its plan, which is Lesson Plan (RPP). The observation sheet of the learning implementation was filled by the class teacher as the observer. The analysis result of the observation sheet toward $\mathrm{X}_{1}$ got 3,93 as the average score and 5,00 for $\mathrm{X}_{2}$. As the conclusion, snake and ladder learning media to enrich Indonesian vocabulary of $4^{\text {th }}$ grade students was practical to be utilized in thematic instruction

\section{Conclusion}

From findings and discussion part, it can be concluded that the snake and ladder learning media to enrich Indonesian vocabulary of $4^{\text {th }}$ grade students in thematic instruction was proven as a valid product from the material and media sides. The product was qualified as an effective product since it was able to achieve the learning objectives. The students could also comprehend and enrich their Indonesian vocabulary easily. The developed product was a practical product to enrich $4^{\text {th }}$ grade students' Indonesian vocabulary since the learning process was suitable with the plan.

\section{Daftar Pustaka}

Abdul Kadir dan Hanun Asrohah. 2015. Pembelajaran Tematik. Jakarta: PT: Rajagrafindo Persada.

Cecep Kustandi dan Bambang Sutjipto. 2013. Media Pembelajaran, Manual dan Digital. Bogor: Penerbit Ghalia Indonesia.

Dian Hikmayana. 2013. Meningkatkan Kosa Kata dalam Pembelajaran Bahasa Indonesia melalui Permainan Ular Tangga. NOSI, Volume 1 Nomor 1, Maret 2013. ISSN 2337-8425.

Emzir. 2010. Metodologi Penelitian Pendidikan: Kuantitatif dan Kualitatif. Jakarta: Rajawali Pers.

Trianto. 2010. Mendesain Model Pembelajaran Inovatif- Progesif. Jakarta : Kencana. 